\title{
頸部悪性腫瘍に対する制癌剂の腫瘍局所灌流
}

\author{
酒 井 克 治*
}

はじめに

末期悪性腫瘍患者に対する制癌化学療法の 1 つとして, Klopp ら (1950) は, 制癌剤の間歇的動脈 内投与法を案出し，てれが制癌剤の全身性投与法にまさるものであると報告した。その後，われわ れは，Klopp らの方法をさらに検討，発展させて，てれを臨床上にひろく応用して来た。さらに， 1962年に至り, Sullivan らは，腫瘍栄養動脈内に挿入，留置された polyethylene 管を加圧ポンブ に接続し，持続的，長時間にわたつて制癌刘を注入する動脈内持続注入法を提唱した。いずれにせ よ，腫湯存在部位を栄養する主幹動脈内に注入され薬剤は，当然腫瘍組織内に直接分布し，しかも その到達量が大きい。したがつて，全身を循環する薬剤量は減少し，ひいては制癌剤による全身障 害がすくなくなる。

しかし，悪性腫瘍がすでに広範囲に拡大しているもの，腫瘍存在部の主幹栄養血管を分離するて とが困難なもの，あるいは術後再発例のでとく，すでに栄養血管が結禁されているものでは，栄養 血管内へ挿管しえないてとがすくなくない.

1958年，Greech らは人工心肺装置をもちいる制癌剤の腫瘍局所灌流法を考案し，制癌剤の局所 性投与法に新分野を開拓した。乙の制癌剤の局所灌流法は，その後，本邦の研究者によつても追試 されて，すぐれた制癌剤投与法の 1 つであることが確認され，その灌流域は，四肢から腹部，骨盤 内臟器, 頭部にまで拡大された。しかし, 胸腔内臓はもちろん, 胸壁, 頸部の悪性腫煬において は，その栄養血管の遊離と，選択的挿管が困難であるため，いわゆる定型的腫瘍灌流を行ない難い とされて来た。とくに, 頸部悪性腫瘍再発例のなかには, 初回手術のさい, radical neck dissection が行なわれるととが多く，したがつて，乙れらに対しては，制癌剤の動脈内挿管投与法ないし定型 的腫瘍局所灌流法を行なうととが困難である.

われわれは，すでに1959年以来，四肢，骨盤，腹部，頭部における手術不能の末期悪性腫陽例に 対して，频癌剤の腫瘍灌流を行なつて来たが，さらに頸部，胸部などの上半身に発生した末期悪性 腫瘍あるいは全身性に発生，もしくは転移した末期例に対する腫煬灌流法を開発すべく努力を重 ね，以下にのべる域外低温下灌流あるいは全身灌流なる特殊灌流法を考案した。

\section{域外低温下腫瘍灌流（第 $\mathbf{1}$ 図）}

本法では，開胸することなく，下行大動脈および下 大静脈を横隔膜上部で遮断したうえで，上半身のみに は自己の心肺によつて大量の制癌剤を循環せしめ，他 方, 体循環から遮断された下半身には, 人工心肺装置 を接続，冷却灌流を行なつて，下半身を冬眠状態にお き, 下半身藏器とくに消化管および造血臟器を, 上半 身血中から漏洩，移行して来る制癌剤より保護しよう とするものである.
本法の実施には，まず患者に気管内㨀管麻酔を施し たうえ，胸骨および両側腸骨稜からできるだけ大量の 骨髄血を採取する。乙れをただちにヘパリンを加えた ハンクス液中に浮遊せしめ, 低温下に保存しておく。 ついで,片側鼠径部に皮切をおき, 大腿動・静脈を露 出し，それぞれ小切開を加えたうえ，cuffつきdouble lumen catheter を中枢側に向つて插入する. catheter の cuff の位置を, 動脈側では腹大動脈内で腹腔動脈

* 大阪市立大学医学部第 2 外科学教室（主任：白羽弥右衛門教授） 
第 1 図 域外低温下腫湯灌流

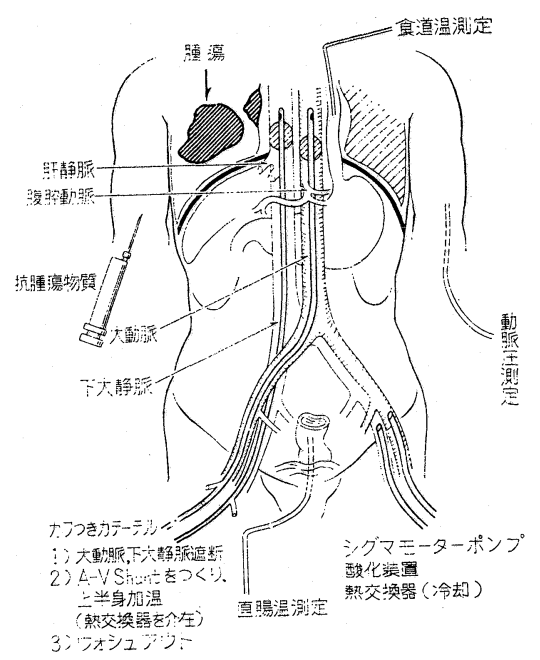

分岐部より頭側，静脈側では下大静脈内で肝静脈流入 部より頭側に位置せしめる.

一方，他側の大腿三角部にも同様の皮切を加え，そ の大腿動・静脈を露出，遊離したのち，血管壁に切開 を加え，乙てから動・静脈の内径に一致する Rüsch catheter を中枢側に向つてそれぞれ約 $7 \mathrm{~cm}$ 挿入し， てれらの体外端を人工心肺装置に接続する.

ついで， cuff catheter の体外端を接続して，下行 大動脈と心側下大静脈との間に短絡を形成し，ての回 路内には別の熱交換器をいれておく。

以上の準備が終つたならば，動脈側，静脈側の順序 で cuff のなが 76\% urografin を徐々に注入し, 大動脈および下大静脈の血流を完全に 遮断する。 ま た，cuff の位置やその破損の有無などは，ただちに撮 影するレ線写真によつて確認できる。ついで，上腹部 に装着された pneumatic tourniquet をふくらませ
て, 腹壁動・静脈を圧迫し, 副血行路を遮断する. ただちに，人工心肺装置の運転を開始し，下半身の 冷却灌流を行なうとともに，上半身血は，さきにつく られた $\mathrm{A}-\mathrm{V}$ shunt を通じて加温する，直腸温が下 降しはじめるのをまつて, 肘静脈内へ大量の制癌剤を 投与する．直腸温か $24^{\circ} \mathrm{C}$ 亿達したのちには，下半身冷 却灌流を一時中止し, 直腸温の変動をみながら，乙れ がほぼ20ㄷを保つように流量を調節する。

制癌剤投与後一定時間を経たのち, 下半身の復温過 程にはいるのであるが，その直前，ヘパリン加新鮮血 をもちいて，上半身血の wash out を行なう。すなわ ち，まず下半身の体外循環にもちいられた人工心肺装 置の送血管を，さきに下大静脈内に挿入しておいた cuff catheter の体外端に接続する。同時に大動脈内 へ插入された cuff catheter の体外端を解放し, 動脈 血を潟血しながら, 酸素加へパリン新鮮血を下大静脈 内へ，ポンプの力をかりて送入する，ての方法によれ ば, 短時間 $(3 \sim 5$ 分)内に大量の血液 $(1,000 \sim 3,000$ $\mathrm{ml}$ ）をおきかえることができる。乙の wash out 亿 より，上半身血中の残存制癌剤はほとんどすべてが除 去される。

Wash out 終了後には，ただちに下半身の復温をは かるために，熱交換器による冷却を加温にきりかえ る. ついで, cuff 内の urografin を徐々に吸引, 排 除するとともに，上腹部に装置しておいた pneumatic tourniquet を解除する. Cuff catheter を徐々に抜去 し，血圧に変動のないととを確認したならば，対側大 腿動・静脈内に捙入された Rüsch catheter を抜去す る. 血管壁に加えられた切開創を Carrel 法にしたが つて修復し，止血が完全なととを確認したうえで，創 を閉鎖，ついで抗へパリン剂，硫酸プロタミン $1 \mathrm{mg} /$ $\mathrm{kg}$ を静脈内一点滴注入する。

\section{全 身 灌 流}

悪性腫場患者には高令者が多く，したがつて，動脈 の硬化性病変をもつものがすくなくない，ひいては， 高度な動脈硬化のために, 腹大動脈内に cuff catheter を挿入しえない症例にしばしば遭遇する。てのような 症例や，全身に発生した悪性腫瘍，もしくは全身転移 を来たした症例を対象に，われわれは制癌剤の全身灌 流なる方法を案出した。

患者に気管内挿管麻酔を行なつたうえ，胸骨および 腸骨稜からできるだけ大量の自家骨髄を採取し, 前述
の域外低温下灌流のときと同じ要領でハンクス液中に 浮遊せしめ，低温下に保存しておく，ついで，大量の 制癌剂を肘静脈内に徐々に投与し，一定時間放置す る。

その後, 片側の大腿三角部に約 $7 \mathrm{~cm}$ の皮切を加え, 大腿動・静脈を露出し，乙れに小切開を加えて cannulation を行なう。動脈側 catheter を人工心肺装 置に接続し，酸素加血を送入するとともに，静脈側 catheter から瀉血する，乙のさい，潟血量にみあう血 
液を送入し，血圧を一定に保つよう心がけなければな らない.すなわち, 薬剤含有血液の wash out を目的 としたおきかえ輸血が行なわれるわけである。われわ れが行なつているおきかえ輸血量は $2,400 〜 6,000 \mathrm{ml}$ にのぼるが，この方法によれば，上述量を 5～15分間 でおきかえることができるのみならず，血液中薬剤の
約85\%を wash out することができる。また，われわ れは，おきかえ輸血そのものにも抗癌効果を期待して いるので，できるだけ大量の健康人血液をもちいて wash out することにしている. 全身灌流後24～48時 間を経てから，さきに術前採取しておいた骨髄を自家 移植する.

腫瘍灌流にもちいられた制癌剂とその量

今日，実地臨床上にもちいられている数多くの制癌 剤のすべてが，必ずしも腫瘍灌流に適しているわけで はない，腫瘍灌流では，体外にある人工心肺装置内を 体内血液が循環するのであるから，灌流時間が長びけ ば長びくほど,灌流血液の化学的,物理的変化が累積さ れて来る。また, 灌流をつづけると, 灌流域内血中の制 癌剤が副血行を介して，全身循環血中へ漏洩して来る ので, 長時間にわたる灌流は, 灌流域内のみの制癌剤濃 度を高く維持しようとする腫瘍灌流本来の目的にそう ことができない，したがつて，腫瘍灌流にもちいる制 癌剤としては, 短時間作用性薬剤が適しており, 代謝 拮抗剤のごとき長時間作用性薬剂は不適当である。な お，抗腫瘍性抗生物質の 1 つである mitomycin $\mathrm{G}$ (以 下 MMC と略記する) は，その構造のなかく ethylenimine 基をもち，アルキル化剤の1つと考えられる
のみならず，即効性であるので，われわれはてれを腫 瘍灌流仔んでもちいている。

ところで，腫瘍灌流は，覀性腫瘍に対する衝撃療法 の1つであるから，乙れには血流遮断領域内の正常組 織あるいは臓器が障害されない最大量の制癌剤をもち いるととがのぞましい，われわれは，域外低温下腫瘍 灌流にさいしては， MMG $0.6 〜 0.8 \mathrm{mg} / \mathrm{kg}$ または cyclophosphamide (Endoxan, EDX と略記する) 30 $\mathrm{mg} / \mathrm{kg}$ をもちい，全身灌流には上述量の $1.2 \sim 1.5$ 倍 量を使用した。

元来，感染症の治療には，まず起因菌を分離して， その抗菌性 化学療法剤に 対する 感性を 測定したうえ で，もつとも抗菌力の強い薬剤を選択，使用するのが 常法である。乙れと同じく，制癌化学療法において も，治療対象となる腫瘍細胞が感性を示す制癌剤を選

第 1 表 SDI 法によつてえらばれた制癌剤の臨床効果

\begin{tabular}{|c|c|c|c|c|c|c|}
\hline $\begin{array}{l}\text { 性 } \\
\text { 年令 }\end{array}$ & 病名 & 制癌威と & SDI & 灌流法 & 効 & 転 \\
\hline $\begin{array}{l}0^{7} \\
44\end{array}$ & 肛門癌再発 & MMG & 96.9 & 骨盤 & 腫瘤縮小， 6 週後直腸切断 & 8 力月後死亡 \\
\hline $\begin{array}{l}0^{7} \\
37\end{array}$ & 肛 門 癌 & $\mathrm{MMG}$ & 96.8 & " & 腫瘤縮小， 6 週後直腸切断 & 14 力月生 \\
\hline $\begin{array}{l}0^{7} \\
60 \\
\end{array}$ & 直 腸 癌 & MMG & 82.8 & " & 腫瘤縮小 & 6 力月後死亡 \\
\hline $\begin{array}{l}\sigma^{7} \\
70 \\
\end{array}$ & 後腹膜腫瘍 & MMC & 92.1 & 腹部 & \begin{tabular}{|l}
$\mid$ 腫瘤縮小 \\
右季肋部痛消失
\end{tabular} & 7 力月後死亡 \\
\hline $\begin{array}{l}0^{7} \\
10\end{array}$ & 細 網 肉腫 & EDX & 81.5 & 全身 & 腫瘤消失 & 3 年 6 力月生 \\
\hline $\begin{array}{l}0^{7} \\
37\end{array}$ & " & MMG & 100.0 & " & 腫瘤著明に縮小 & 1 年 7 力.月後死亡 \\
\hline $\begin{array}{l}0^{7} \\
50\end{array}$ & " & NMO & 100.0 & " & & 1 力月後死亡 \\
\hline $\begin{array}{l}\text { 우 } \\
62\end{array}$ & 右乳癌再発 & MMG & 33.1 & " & \begin{tabular}{|l|} 
腫瘤縮小 \\
賁瘍浄化
\end{tabular} & 7.5力月死亡 \\
\hline $\begin{array}{l}0 \\
13 \\
13\end{array}$ & 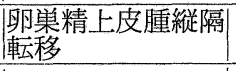 & EDX & 74.3 & " & 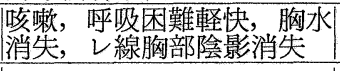 & 14力月生 \\
\hline $\begin{array}{l}\sigma^{7} \\
35 \\
\end{array}$ & 殬丸胎生癌 & NMO & 78.5 & " & 腫瘤縮小，4 週後剔出 & 21 力月生 \\
\hline $\begin{array}{l}0^{\pi} \\
63 \\
\end{array}$ & 右 肺 癌 & MMG & 86.0 & " & & 2 力月後死亡 \\
\hline $\begin{array}{l}0^{\pi} \\
49\end{array}$ & 骨盤骨肉腫再発 & NMO & 99.5 & " & 腫瘤縮小 & 5 力月後死亡 \\
\hline
\end{tabular}

有効率 $83.3 \%$

対照：103例の有効率 $73.8 \%$ 
出しててれを用いることができれば好都合である。. そ の方法として，てれまで INK 法，.SSI 法および組 織培養法なぞが利用されてきた。われわれも，最近で は腫瘍灌流を行なうに当つて，必ず対象腫愓の一片を とりてれについて SDI 法を行なつて, 腫瑒細胞の 制癌剤感性試験を試みている。第 1 表は，SDI 法が施 行されたのちもつとも係数の高い薬剤をえらんで, 腫 瘍灌流が行なわれたのちにみられた有効率をあらわし ている，無選択に制癌剤をもちいた場合にくらべて， 有効率がやや高くあらわれている。もちろん，乙の成 績から，ただちに SDI 法の価值を即断するてとはで きないにしても，信頼すべき適応制癌剤選択法のない 今日，SDI 法は，一応試みられてよい1つの方法であ ると思われる。

私は，さきに腫愓局所灌流にもちいる薬剤として は，短時間作用性薬剂が適でているとのべた。 しか し，単に短時間作用性薬剤といつても，その数が多 く，それぞれ異なつた作用機序をもつている。 とと に，該薬剤と腫煬細胞あるいは生体細胞が汉応するた みに必要とする時間は一定しておらず，薬剤の種類に よつて大きな差がみられる。たとえば Mark らによ ると， nitrogen mustard の骨髄細胞に対する作用は， 薬剤投与後 2 分以内がもつとも強く, 4 分以内にはほ とんど終焉するとのととである，また，EDXはnitrogen mustard 々同系列のアルキル化剂ではあるが， 製浏そのものは不活性な transport form であり，乙 れが生体内あるいは腫愓組織内へ導入されてはじめて active form にかえられるものである. したがつて， EDX が腫煌細胞あるいは正常細胞と反応するのに要 する時間は, nitrogen mustard にくらべてより長い のではないかと推察される。

今日まで，腫湯灌流の持続時間を定めるに当つて は，乙れにもちいる制癌剤の種類のいかんを問わず， むしろ灌流中の局所血液のなか力汃ら，全身血中へ漏洩 する薬剤量と，その時間的推移，すなわち一定量の薬 鼡漏洩がおてるまでの時間をもつて限界とした研究者 が多かつた。したがつて，四肢灌流では，全身血中へ の漏洩がきわめてすくないので，その灌流時間が長か つた。しかし, 骨盤, 腹部灌流などでは, 灌流開始数 分後すでに，全身血中への薬剤漏洩がはじまり，まも なく全身循環血中と灌流域血中制癌剤濃度が近接值を 示すに至るものである．したがつて，ての部の悪性腫 瘍に対してはむしろ短時間灌流が行なわれて来た。し かし, 薬剤漏洩問題のほかに, 腫湟灌流にもちいられ
る制癌剤が，腫愓組織細胞と反応するためほ必要とす る時間を測定したうえ，当該制癌剂に必須充分な時間 内にかぎつて，腫瘍灌流を行なうのがよいと考光られ る.

さきに，われわれは，動物実験を行なつて， MMC がラットの生体細胞あるいは移植された吉田肉腫細胞 と結合しはじめるのは， $\mathrm{MMC}$ 投与後15分以内であ り, 投与後 30 分以内にはすでに結合過程を終了してい るのではないかとの成績をえた。 また，EDX につい ても同様の実験を行ない，EDX の結合反応は，EDX 投与後30分以内にはじまり，45分に終焉していると報 告した。したがつて，てのような短時間作用性制癌剤 を腫瘍灌流にもちいる場合には，それぞれの薬剤がも つ作用時間内にかぎつて灌流するのみでも，その効果 が期待されるのではながらうか。 むしろ，一定の作用 時間以上にわたる腫漡灌流は, 無意味であるばかりで なく, 正常組織に与える障害を増加し，かつ全身血中 へ漏洩した薬剤が全身性副作用を惹起するてとになる と考えられる，また腫瘍細胞は，正常細胞よりも鋭敏 かつ敏速に制癌剤と反応するとも思われるので，灌流 時間を上述の作用時間内にとどめ，その後はただちに 灌流域中に残存する制癌剤を，薬剤をふくまない血液 をもちいて wash outすれば，正常組織に与光る影響 がすくなくなり，腫場細胞のみを選択的に破壊しうる ものと考光た。

われわれの教室で，MMC または EDX をもちい て全身灌流が行なわれた症例は66例(70回)であるが， そのうちの最近 43例（47 回）における灌流時間は， MMC をもちいた場合は15分以内，EDX については 30分以内に制限した。 それまでの23例（23回）では， MMG または EDX 使用例ともに60分間灌流を行な

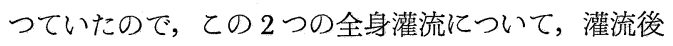
の臨床効果発現頻度をしらべてみた。すなわち，30分

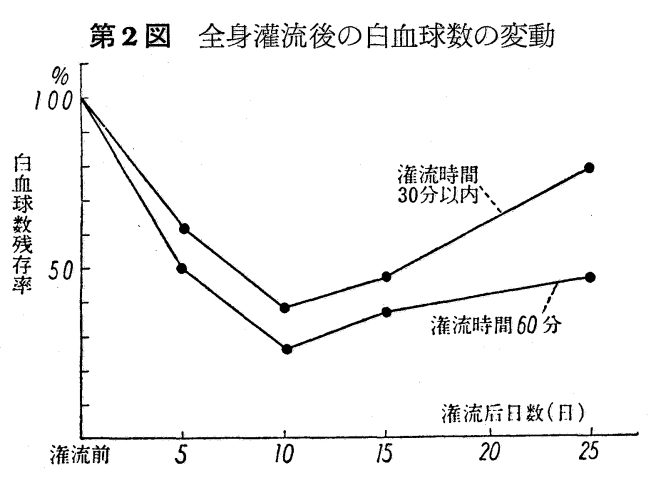


以内灌流が行なわれたもののなかには，腫瘤縮小21回 $(44.6 \%)$ ，腹水減少 4 回 $(8.5 \%)$ ，桨痛軽快 4 回 $(8.5$ \%) がみられ，60分間灌流群においては，腫瘤縮小 9 回 $(39.1 \%)$ ，腹水減少 2 回 $(8.6 \%)$, 路痛軽快 2 回 (8.6\%) を経験した。すなわち，両群の臨床效果発現 率はほほ同じである。

しかし，30分以内灌流群および60分間灌流群におけ る灌流後の末梢血中日血球数の変動をしら心゙てみる と，第 2 図のようであつた。すなわち，30分以内灌流
群の灌流後白血球減少は明らかにすくなく，かつとの 白血球減少症の恢復も速やかであつた，乙れらの成績 からみると， MMC または EDX をもちいる腫湯灌 流では灌流時間を15分または30分以内にとどめても， 制癌剤のあらわす效果は，60分間灌流とかわらず，む しろ，灌流中に抢こる薬剤の全身血中八の漏洩をすく なくしし，制癌郕の全身性副作用を軽減させることが できるわけである。

臨 床 効 果

われわれの教室では，1959年以降今日までに，種々 の部位の覀性腫瘍患者150例に対して，165回の腫瘍灌 流を行なつた。このうち，域外低温下腫演灌流が行な われたもの24例(27回)，全身灌流が行なわれたもの73 例 (80回) であるが，頸部の悪性腫婸に刘して前者が 行なわれたものは14例(16回)，後者が施行されたもの は31例(36回)である。すなわち，上頻癌再発 3 例，耳 下腺癌再発 1 例, 堠頭癌再発 3 例, 甲状腺癌 1 例, そ の肺転移 3 例, 肺癌頸部転移 1 例, 鯰性癌 1 例, 原発 单不明頸部癌 1 例に対しては域外低温下灌流を行なつ た。また，全身灌流が行なわれた頸部癌 31 例のうち わけは，細網肉腫16例，リンパ肉腫 4 例，肺癌頸部転 移 3 例, 噴門癌ウィル七ョウ腺転移 1 例, 甲状腺癌全 身転移 2 例，耳下腺癌 2 例，肺澏頸部転移 3 例であ る。とれらの症例ば，いずれも進行した末期覀性腫瘍 患者もしくは数回の根治術後の再発例であつた。した がつて，自覚的愁訴も多く，なかでも激しい疼痛に悩 むものがすくなくなかつた，とこらが，灌流後の症例 は，いずれもこれらの苦痛から開放されて，啙痛に基 因する不眠の訴えがなくなつた。また，肺転移例ない し肺癌未期例の多くは，頑固な咳濑，呼吸困難を訴え ていたが，いずれも灌流後にはそれらの症状が消失し t心.

これらの灌流が行なわれた頸部悪性腫晹45例中10例 は灌流後 2 週以内に死亡したので，乙れら早期死亡例 芭除く35例について，灌流後の腫溜の大きさの変化を 㭘討した。すなわち，域外低温下灌流 9 例中 5 例, 全 鸟灌流26例中17例，計35例中22例に腫瘤の縮小または

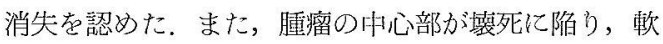
化したものが前群中に2 例, 後群中にも1例みられ た。胃癌根治術後の再発およびウィルヒョウ腺転移例 （38才，女）は，その巨大な頸部腫瘤のため水すらのみ
えなかつたのであるが， MMC 40mg 存もちいる全身 灌流後には，頸部，上腹部腫熘がともにいちしるるしく 縮小した結果，灌流 1 週後には固形食さ先搨取できる ようになつた。細網肉腫, リンパ肉腫例に対しては， すべて全身灌流毞行なつたが，全例が著明に反応し， 頸部腫溜はもちろん全身に発生したリンパ尰がすべて 消失した症例もすくなくない，癌が漬瘍を形成し，励 い肉牙で被われていたものでは，肉芽が浄化され，そ の悪臭が消失した(2例)。また，灌榄前出血していた 癌漬瘍の出血が停止したものも4例経験されている。

症例 $1 ： 52$ 才，女(写真 1 )。昭和40年 9 月左頸部腫

写真 1 原発宩不明頸部癌（類上皮癌）

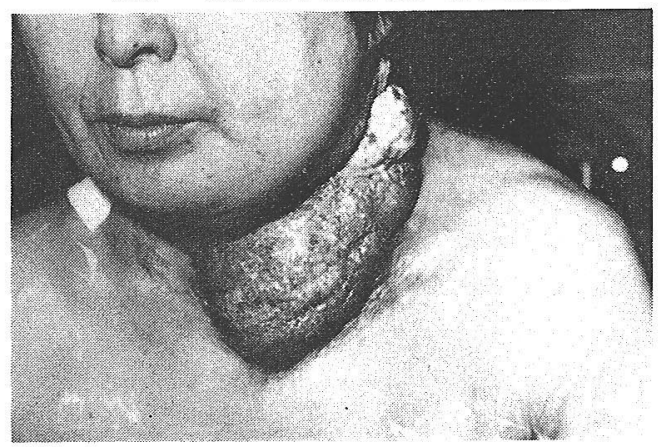

瘤にきずき，剔除術をうけて以来，昭和41年10月15 日，われわれの教室を訪れるまで 5 回にわたり同部尰 湯の剔除，雨発をくりかえしていた，との写真は，来 院時の主董瘤であるが，その1部は漬瘍を形成し，同 部は易出血性であつた。 また，両側鎖骨上窩，腋窝り ンパ節がるいるいと腫脹し，雨側上肢の運動障害预よ び而側指尖に放散する頑固な神経痛㴍疼痛を訴兄てい た，背卧位をとると呼吸困難がつよいので，つ孙に坐 位をとらざるをえなかつた。な打，試験切片組織は類 
上皮癌と誩断され，その SDI 検查では MMG の指 数がもつとも高くあらわれた。

10月21日, $\mathrm{MMC} 42 \mathrm{mg}(0.8 \mathrm{mg} / \mathrm{kg})$ をもちいて域 外低温腫鈞灌流を行なつた。すなわ すriming blood $3,500 \mathrm{ml}$ をもちい, 食道温を $37.5^{\circ} \mathrm{C}$, 直腸温 $30^{\circ} \mathrm{C}$ 亿保 つたうえ， MMC 全量存 1 回に肘静脈内人 one shot 注入した。灌流時間は15分，灌流終了後の wash out 量は3,000 $\mathrm{ml}$ である。

その結果，灌流直後から，術前訴えていた雨上肢一 の放散痛が全く消失し, 背㓡位をとつても呼吸困難を 来たすととがなく，充分睡眠しうるようになつた。

写真 2 は，灌流後19日目の頸部腫溜を示している。 腫瘤はやや縮小するとともに，ほとんどが壇死に陌 り，腫瘤の 1 部が自然に脱落した。また，灌流前易出 血性であつた潰瘍から出血も停止した，しかし，灌流 後 1 力月目頃から, 腫瘤が再び増大しはじめ, 灌流後 3 力月目に死亡した。

症例 $2: 70$ 才，女，写真 3 は，昭和41年11月10日来 院時の主腫瘤を示している。また，左側頸部から左銷 骨上甞に加けて多数のリンパ節転移を認め，その一部 の組織診断は悪性耳下腺混合腫瘍であつた。 また， SDI 試験では，MMC 88, 5-FU 79, EDX 74 との指

写真 2 同上，惐外低温下腫瘍灌流後19日目

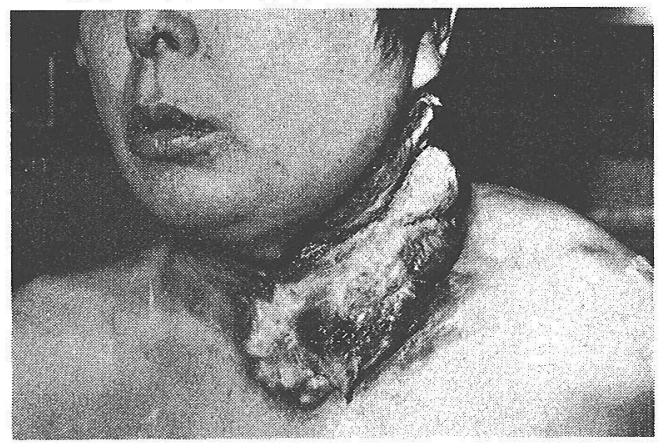

写真 3 左悪性耳下腺混合腫痯

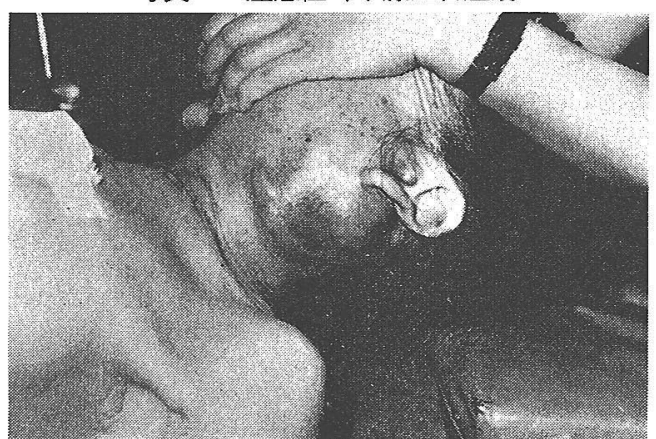

写真4 同上，胸部レ線像

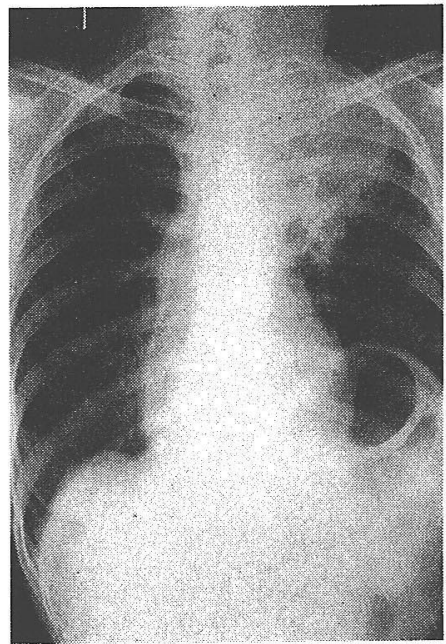

写真5 同上，全身灌流後 8 日目

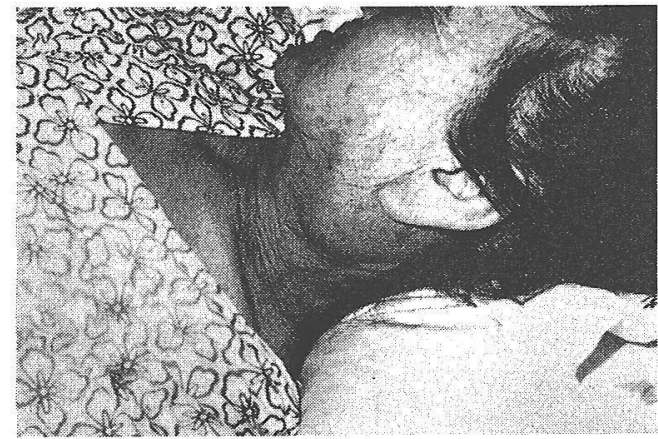

写真 6 同上，全身灌流後14日目脸部レ線像

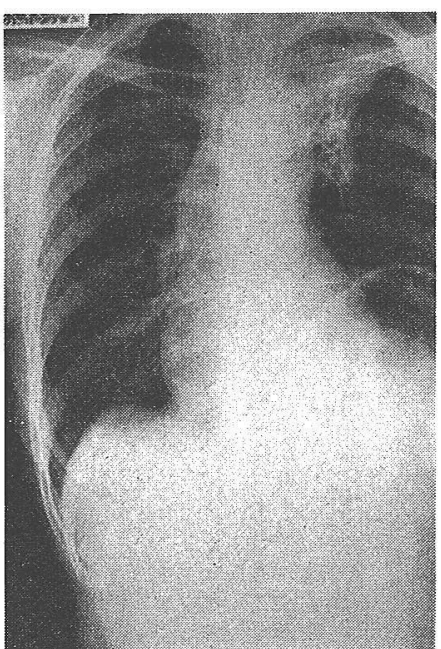


写真 7 同上, 灌流後29日目, 左耳下腺腫湯剔除 および左 radical neck dissection 施行, 術後10日目

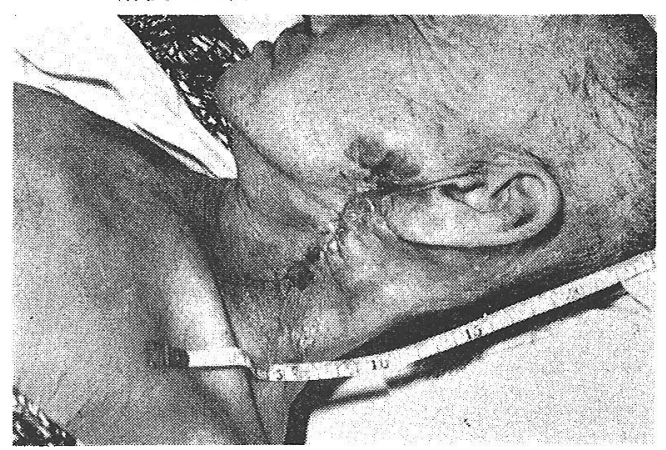

数をえた。また，リンバ節転移は，縦隔洞にもおよ び，左肺上野は，写真 4 亿示すような肺拡張不全を呈 していた。

昭和41年11月21日, MMC $34 \mathrm{mg}(1 \mathrm{mg} / \mathrm{kg})$ を它 いて全身灌流を行なつた，灌流時間は15分，灌流後へ パリン加血3,000mIをもちいておきか光輸血を施行, 灌流後24時間目には，灌流前採取してわいた骨㕼血 (有核細胞数 $1.3 \times 10^{9}$ コ) 自家移植した。

その結果，左耳介下部および左側頸部腄瘤は日をお つて縮小しはじめ, 灌流後 8 日目に写真 5 亿示すよう そなつた，また，写真 6 は，灌流後14日目の胸部レ線 像であつて, 縦隔洞内の転移腫瘤が縮小した結果, 左 肺上野の肺拡張不全がいちじるしく改善されている。

このように，腫掦灌流の効果が著明にみられたの で, 灌流後29日目, 左耳介下部の腫瘤を剔出し, 併せ て左頸部颜清手術を施行した。写真 7 は, 剔出術後 10 日目のものである，現在家事に従事しており，その経 過落㛜重に観察している。

\section{腫瘍灌流の合併症}

前述のように，域外低温下あるいは全身灌流の対象 となつた症例には，進行した末期癌例が多く，したが つて，とくに慎重な灌流後管理在要とする，大血管 孯断解除後の血压低下が灌流終了後にも持続したり, ヘパリン中和のためにもちいられるプロタミンの点滴 注入に由来すると思われる血圧低下か溶易に回復しな いとともある。乙のような場合には，必要に応心゙， 昇王剂，輸血，輸液あるい副繁皮質ホルモン剂を強 力に投与しなければならない。しかし，腫瘍灌流に伴 なうもつとも頻度の高い合併症は，大量の制癌剤投与. に由来する全身骨㗙障害である。自家例の域外低温下 腫湯灌流24例 (27回) 中 10 例, 全身灌流73例 (80回) 中 15
例が，灌流 7〜10日後に無顆粒球症に楩り，強力な治 療にも反応せず死亡した。しかし，てのような高度の 白血球減少を来たした症例のほとんどは，われわれが 初期に経験した長時間灌流例であつて，前述のでとき 短時間灌流を行なうようになつてからは，灌流後白血 球減少の程度がいちじるしく軽減された。

未梢血中白血球減少と相俟つて, 血小板数减少を示 すものもすくなくない，とくに，域外低温下および全 身灌流が行なわれた症例の約半数では，血小板数が10 万もしくはそれ以下にまで減少した。るをると，体外 循環にヘパリン加血液をもちい，插管にさいしても全 身血のヘパリン化なはかり，さらに灌流終了後へパリ ン加血液で wash out t行なうので，たと光，灌流終 了後硫酸プロタミンでへパリンを中和しておいても, 手術創や骨䯙穿刺部からする後出血がおこり，てれが 皮下溢血としてあらわれることがすくなくない．しか し, 灌流後 1 週以降の出血時間および㠜固時間には, いずれも著変がみられず，正常值を示していた。

MMC および EDX 亿よる域外低温下または全身 灌流例のながには，その後の頭髮の著明に脱落したも のが多い。とくに，域外低温下腫㳻灌流27回のうち， 早期死亡10例を除く17回中 9 回において，激しい頭髮 脱落を認めた。これは，高濃度の制癌剤が上半身にか ぎつて循環する事実を示しているわけであるが，ひい ては，上半身の悪性腫晹住対する本灌流法の意義老裹 づける1現象でもある。

そのほか，喉頭澏の1例に域外低温下灌流を行なつ

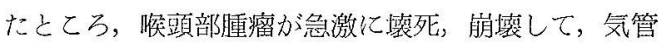

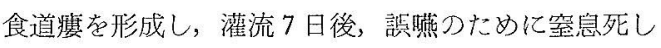
たものがある。

\section{遠隔成績}

さて，われわれの教窒で頸部悪性腫崲に対して域外 低温下あるいは全身灌流が行なわれた45例の灌流後生 存状沉をしらべてみるとつぎのようであつた。すなわ ち，域外低温下灌流が行なわれた14例中音信不通 1 例 を除々13例は，そのうち11例が灌流後 3 力月以内に死 亡し, 残り 2 例寻 1 年以内に死亡した. 全身灌流群 31 例中20例は，灌流後 6 力月以内に死亡し，1例は 1 年 7 力月, 1 例は 1 年 8 力月目に死亡した。残り 9 例が 生存しているが，9例中 4 例は灌流後なお日が浅く, 現在経過観察中である。しかし，他の生存 5 例は，い ずれる細網肉蕾例であるが，灌流後すでに 2 年以上を 経過していて，なお再発の徴がみられない。それでれ

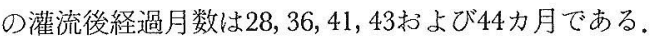




\section{む す び}

末期悪性腫瘍患者に対する制癌剤の局所性投与法の 1 つとして，腫瘍局所灌流法が発表されたの は，1958年のととであつた。われわれは，早くから嘍癌剤の局所性投与法に関する研究をつづけて 来たが，1959年以降腫瘍局所灌流法についてもその研究をはじめ，独自の立場から，上半身悪性腫 瘍に対する域外低温下腫瘍灌流および全身性腫瘍に対する全身灌流なる新しい方法を開発し，ての 新しい腫瘍灌流法をもちいて, 手術不能の頸部悪性腫瘍を治療してみた。 その結果, 一時的にもせ よ, 灌流後自, 他覚的所見の改善されるものが多くみられ，なかには，灌流後の症状改善期にあら ためて根治手術を行ないえたものもある．制癌剤の腫瘍局所灌流は，末期の頸部悪性腫瘍例にも試 みてよい治療法の1つである.

本論文の要旨は, 昭和 41 年 12 月 7 日, 大阪市で開催された第 12 回頭䅡部腫瘍研究会において報告した.

(稿を終るにのぞみ，御校閲をいただいた白羽弥右衛門教授に樑謝する。)

文献

1) Klopp, C.T., et al. : Fractionated Intra-Arterial nts. S.G.O. $116: 232,1963$ Gancer Chemotherapy with Methyl-Bis-Amine Hydrochloride. Ann. Surg. 132 : 624, 1950

2) Sullivan, R.D. : Continuous Arterial Infusion Cancer Chemotherapy. Surg. Glin. North Am. 42 : 365, 1962

3) Creech, O. Jr., et al. : Ghemotherapy of Cancer. Regional Perfusion Utilizing an Extracorporeal Gircuit. Ann. Surg. 148 : 616, 1958

4) Mark, V.H.,et al. : Determination of the Biologic Toxicity of Circulating Alkylating Age-
5）土居進 : 上半身の末期悪性腫瘍に対する制癌剤の 域外低温下腫癔灌流に関する研究, 阪市大医誌 $12: 405,1963$

6）白羽弥右衛門, 酒井克治 : 制癌剤の動脈内插管投 与に関する研究(1), 阪市大医誌 $13: 257,1964$

7）白羽弥右衛門，他：制癌剂の腫瘍局所灌流に関す る研究, 阪市大医誌 $15: 311,1966$

8) 酒井克治 : 腫瘍局所灌流化学療法の問題点, 最新 医学 $19: 2326,1964$ 